Original Research Article

\title{
Antimicrobial and antioxidant property of Curcuma longa Linn.
}

\author{
Intan Atirah Muhamed, Wan Amir Nizam Wan Ahmad, \\ Nurul Syahida Ramli, Noraini A. Ghafar*
}

School of Health Science, University of Science Malaysia, Health Campus, Kubang Kerian Kelantan, Malaysia

Received: 05 September 2019

Revised: 08 October 2019

Accepted: 09 October 2019

*Correspondence to:

Dr. Noraini A. Ghafar,

Email: norainiag@usm.my

Copyright: (C) the author(s), publisher and licensee Medip Academy. This is an openaccess article distributed under the terms of the Creative Commons Attribution NonCommercial License, which permits unrestricted noncommercial use, distribution, and reproduction in any medium, provided the original work is properly cited.

\begin{abstract}
Background: Curcuma longa Linn. (Zingiberaceae family) plant or turmeric is known to possess pharmacological properties at relatively nontoxic doses. The study was carried out with the aim to evaluate the antimicrobial and antioxidant activities of C. longa L.

Methods: Ethanolic rhizome extract was applied against Staphylococcus aureus and Salmonella typhi using disc and well diffusion methods. Antioxidant of $C$. longa L. was determined by measuring 1,1-Diphenyl-2-picrylhydrazyl (DPPH) radical scavenging activity.

Results: The ethanolic extract of rhizomes showed inhibitory activity against Gram-positive $S$. aureus bacteria, whereas the Gram-negative S. typhi bacteria were resistant toward the ethanol extract. Zone of inhibitions against $S$. aureus were $7 \mathrm{~mm}$ and $11 \mathrm{~mm}$ by disc and well method, respectively. For antioxidant activity, DPPH radical scavenging activity of ethanolic extract of $C$. longa L. was set against butylated hydroxytoluene (BHT). It was shown that the value of half maximal inhibitory concentration $\left(\mathrm{IC}_{50}\right)$ of rhizome extract was higher than standard control. The dose response curve was utilized to determine the half maximal $\mathrm{IC}_{50}$ value for each sample. The $\mathrm{IC}_{50}$ of rhizome extract is 21.25 $\mu \mathrm{g} / \mathrm{ml}$, while the value $\mathrm{IC}_{50}$ for BHT is $12.42 \mu \mathrm{g} / \mathrm{ml}$.
\end{abstract}

Conclusions: The finding suggested turmeric rhizome-extract as a good candidate in the search for a natural antimicrobial and antioxidant agent.

Keywords: Antioxidant, Antimicrobial, Curcuma, Disc diffusion, Scavenging activity

\section{INTRODUCTION}

Many compounds derived from plant are used in medical to treat disease. Curcuma longa L. plant or known as turmeric is a popular spice in Southern Asia and Indian subcontinent. Curcumin is the main phytochemical compound in turmeric which gives yellow colour to turmeric. Curcumin has showed antimicrobial, antidiabetic, anti-inflammatory, anticancer and antioxidant activity. ${ }^{1}$ Altunatmaz et al found curcumin to be effective in wound therapy and it works against food pathogens. $^{2}$
From the previous studies, extract of Curcuma longa Linn rhizome demonstrated antibacterial activity against Gram-positive and Gram-negative bacteria in vitro and in vivo. Most methods used for testing its antibacterial activity in vitro studies are disc diffusion and broth dilution method. ${ }^{3,4}$

Antioxidants are the substances that play vital role in free radical scavenging and chain breaking of oxidation reactions both in vivo and in vitro. They are good preservative compounds and can be found abundantly in natural foods. Thus, daily intake of antioxidant foods can create natural prevention method through enrichment of preventive compound. In addition, antioxidants also 
possess prevention of oxidative reaction in cosmetic product and pharmaceuticals. ${ }^{5}$

The antioxidant compounds are important to prevent freeradical induced oxidative stress. Some research shows plants contain polyphenols and anthocyanins which are active phytochemicals that have benefits in decreasing the rates of cardiovascular diseases, lowering the risk of cancer, stroke, and type 2 diabetes and preventing obesity. In addition, phytochemical compounds in plant derived products have ability to bind to enzyme and inhibit their activity. For example, the presence of enzyme inhibitor such as $\alpha$-glucosidase, $\alpha$-amylase, and lipase in the plant derived products can help to control level of blood glucose in patients with type 2 diabetes and to prevent obesity. ${ }^{6}$

The bioactive chemical constituents in turmeric have been extensively investigated. Curcuminoids (mostly curcumin) and essential oils (primarily monoterpenes) are the major bioactive constituents show different bioactivities. Calebin-A, vanillic acid, vanillin, quercetin, and other phenolic compounds have also previously been identified from turmeric.?

Currently, antibiotic resistance become the greatest challenge globally to effective treatment of infections. Microorganisms undergo genetic materials exchange with other organisms to protect themselves against natural antibiotics. Thus, the interest of using plant extracts for this purpose is growing since the extracts possess antioxidant and antimicrobial activity. ${ }^{8}$ From previous study, the phytochemical analysis revealed that the methanol, ethanol and distilled water extract have chemical compounds that have been found possessing antibacterial activities. ${ }^{9}$ This study was conducted to determine antimicrobial property of curcumin against Staphylococcus aureus and Salmonella typhi by disc and well diffusion methods, besides to compare the sensitivity of both methods. We also aimed to determine the antioxidant property of ethanolic rhizome extracts.

\section{METHODS}

\section{Preparation of plant and extraction method}

Plant and rhizome of C. longa L. was collected from fresh market in Kota Bharu Kelantan, a state in east coast of Malaysia. Authentication of plant and rhizome were made at Kuliyyah of Pharmacy, International Islamic University Malaysia (IIUM), Pahang. A voucher specimen (PIIUM 0280-1) was verified by botanist from the Faculty of Science and Technology, the National University of Malaysia (UKM), Selangor. A kilogram of rhizomes was cleaned and cut into slices. The rhizomes were then dried completely in the incubator for a few days at $37^{\circ} \mathrm{C}$ before grounded into powder.

In this study, ethanol extract method was used to study antimicrobial activity. Approximately $30 \mathrm{~g}$ of rhizome powder was added into the absolute ethanol solvent to make $20 \%$ concentration. The mixtures were made in sterile Erlenmeyer flask. Then, the flask was wrapped with aluminium foil to avoid evaporation and exposure to lights. The flask was placed on a platform shaker for 3 days at $7 \mathrm{rpm}$ and room temperature. After 3 days of soaking, the mixtures were unloaded into sterilized petri dish. ${ }^{9}$ The petridish weighed before and after loading the mixtures. The extract was dried completely under the fume hood until a consistent weight is achieved for 3 times. The extract was collected and stored at $4^{\circ} \mathrm{C}$ until used.

\section{Microbial strains preparation}

The strains of $S$. aureus and $S$. typhi used in this study were obtained from the Microbiology Laboratory, School of Health Sciences, Universiti Sains Malaysia (Health Campus), Kelantan. The bacteria were cultured on nutrient agar at $37^{\circ} \mathrm{C}$ for $18-24$ hours. Gram staining was then performed.

\section{Disc diffusion assay}

Approximately $1000 \mathrm{mg}$ of rhizome extract was mixed into $2 \mathrm{ml}$ of ethanol for preparing stock extract. Different concentrations of stock were prepared; $500 \mathrm{mg} / \mathrm{ml}, 400$ $\mathrm{mg} / \mathrm{ml}, 300 \mathrm{mg} / \mathrm{ml}, 200 \mathrm{mg} / \mathrm{ml}, 100 \mathrm{mg} / \mathrm{ml}$ and $0 \mathrm{mg} / \mathrm{ml}$. $20 \mu \mathrm{l}$ of each concentrated extract were pipetted and loaded onto $6 \mathrm{~mm}$ diameter sterile blank discs with dimethyl sulfoxide (DMSO) used as negative control. All impregnated discs were then allowed to dry overnight at room temperature in a laminar flow hood. ${ }^{8}$

The bacteria were cultured on sterile petri dishes containing Muller Hinton agar for $18-24$ hours at $37^{\circ} \mathrm{C}$. On the next day, the cultures were adjusted to match with McFarland 0.5 standard by preparing normal saline suspension. Then, sterile cotton swab was dipped into bacterial suspension and swabbed onto Muller-Hinton agar. Blank discs that already impregnated with DMSO and different concentrations of extract were placed on surface agar by using a needle. Each plate placed 3-4 discs only. Each blank disc was labelled correctly. The plates were incubated at $37^{\circ} \mathrm{C}$ for 24 hours. After 24 hours of incubation, each plate was examined for zone of inhibition. Measured the inhibition zone in millimetres using a ruler. 8,10

\section{Well diffusion assay}

Muller Hinton agar plates were prepared and $S$. aureus and $S$. typhi were cultured on each media plate for 18-24 hours at $37^{\circ} \mathrm{C}$. On the next day, the test bacterium was adjusted to match McFarland 0.5 standard solution. A sterile cotton swab was dipped into bacteria suspension, rotated several times and pressed firmly onto the inner side of the tube above the fluid level removing excess inoculum. Next, the cotton swab was streaked over the entire sterile agar surface by rotating the plate to ensure 
the inoculum evenly distributed. The plates were allowed to dry for 3 to 5 minutes. Then, sterile $1000 \mu$ pipette tip was punched into Mueller Hinton medium to make a well. Approximately $20 \mu \mathrm{l}$ of each concentration extract $(500 \mathrm{mg} / \mathrm{ml}, 400 \mathrm{mg} / \mathrm{ml}, 300 \mathrm{mg} / \mathrm{ml}, 200 \mathrm{mg} / \mathrm{ml}, 100$ $\mathrm{mg} / \mathrm{ml}$ and $0 \mathrm{mg} / \mathrm{ml}$ ) was pipetted and dispensed into each well after the inoculation of the plates with bacteria. DMSO was used as negative control. The plates were labelled and incubated in the incubator for 24 hours at $37^{\circ} \mathrm{C}$. Each plate was examined after 24 hours incubation period. Zones of inhibition (in millimetre) were then measured. ${ }^{9}$

\section{Antioxidant assay}

Antioxidant of $C$. longa $\mathrm{L}$. was determined by measuring 1,1-Diphenyl-2-picrylhydrazyl (DPPH) radical scavenging activity. Firstly, $1.5 \mathrm{mg}$ of ethanolic rhizome extracts dissolved in $1.5 \mathrm{ml}$ of absolute ethanol to produce the final concentration of $1 \mathrm{mg} / \mathrm{ml}$. The mixture was mixed by the vortex. The standard used in this test was butylated hydroxytoluene (BHT) at the same concentration. For DPPH reagent (light sensitive), 0.0079 $\mathrm{g}$ of DPPH powder dissolved in $50 \mathrm{~mL}$ of ethanol. Its final concentration was $0.4 \mathrm{mM}$. Then, $2 \mathrm{~mL}$ of $0.4 \mathrm{mM}$ DPPH solution was transferred into each concentration. The reaction mixture was incubated for about 30 minutes at room temperature. All these processes were conducted in dark environment. The absorbance was measured at $517 \mathrm{~nm}$ in the UV-visible spectrophotometer, using ethanol as a blank. ${ }^{11,12}$

\section{RESULTS}

\section{Antimicrobial property of ethanolic extract}

Curcumin, the major constituent of Curcuma longa Linn. has been found to be effective against Gram-positive and Gram-negative bacteria. The diameter of inhibition zone presented by each disc and well were presented in Table 1.

Table 1: The result of disc and well assay for $C$. longa $\mathrm{L}$. against selected bacteria.

\begin{tabular}{|c|c|c|c|}
\hline \multirow{2}{*}{ Bacteria strain } & \multirow{2}{*}{ Concentrations extract (mg/ml) } & \multicolumn{2}{|c|}{ Zone of inhibition (mm) } \\
\hline & & Disc diffusion & Well diffusion \\
\hline \multirow{7}{*}{ Staphylococcus aureus } & 0 & - & - \\
\hline & 100 & 7 & 12 \\
\hline & 200 & 7 & 11 \\
\hline & 300 & 7 & 11 \\
\hline & 400 & 7 & 11 \\
\hline & 500 & 7 & 11 \\
\hline & DMSO & - & - \\
\hline \multirow{7}{*}{ Salmonella typhi } & 0 & - & - \\
\hline & 100 & - & - \\
\hline & 200 & - & - \\
\hline & 300 & - & - \\
\hline & 400 & - & - \\
\hline & 500 & - & - \\
\hline & DMSO & - & - \\
\hline
\end{tabular}

Negative control=DMSO; -: No inhibition activity.

Based on the table, the ethanolic extract started showing antibacterial activity with the inhibition zone of $7 \mathrm{~mm}$ against $S$. aureus at $100 \mathrm{mg} / \mathrm{ml}$. This diameter of zone was same for the concentration $200 \mathrm{mg} / \mathrm{ml}$ to $500 \mathrm{mg} / \mathrm{ml}$. Meanwhile, $0 \mathrm{mg} / \mathrm{ml}$ (control), and DMSO as negative control was inactive against $S$. aureus. Result from the assay shown no inhibition zone for $S$. typhi at all concentrations $(0-500 \mathrm{mg} / \mathrm{ml})$ tested.

For well diffusion assay, the results shown that Grampositive $S$. aureus bacteria was more compatible to the rhizome extracts as compared to Gram-negative S. typhi. The rhizome extract at all concentrations (100-500 $\mathrm{mg} / \mathrm{ml}$ ) tested, inhibited the growth of $S$. aureus with inhibition zone range 11 to $12 \mathrm{~mm}$. Meanwhile, the extract showed no inhibition activity at all concentrations tested against $S$. typhi. From both results, the well diffusion method showed to be more sensitive than the extract loaded onto blank disc.

According to figure, the rhizome extract only showed effective for the prevention of infections caused by $S$. aureus. Meanwhile, the extract showed no inhibitory activity against $S$. typhi (Figure 1a-d).

\section{Antioxidant assay}

The antioxidant activity of $C$. longa Linn was determined using DPPH free radical-scavenging activity. DPPH radical scavenging activity of ethanolic extract of $C$. longa $\mathrm{L}$. was set against BHT. It was shown that the value half maximal inhibitory concentration $\left(\mathrm{IC}_{50}\right)$ of rhizome extract was higher than standard control. According to Figure 2, dose response curve was utilized 
to determine the half maximal $\mathrm{IC}_{50}$ value for each sample. The $\mathrm{IC}_{50}$ of rhizome extract is $21.25 \mu \mathrm{g} / \mathrm{ml}$, while the value $\mathrm{IC}_{50}$ for $\mathrm{BHT}$ is $12.42 \mu \mathrm{g} / \mathrm{ml}$.

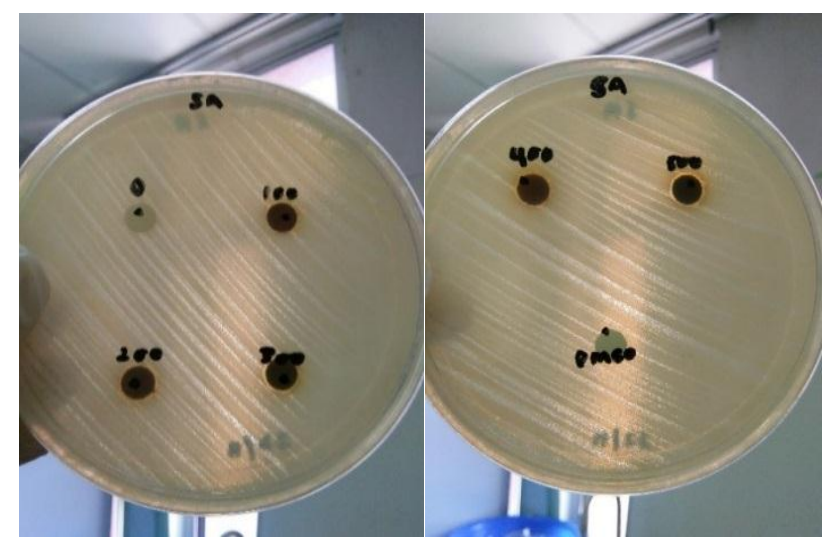

Figure 1a: Inhibition zone of $C$. longa $\mathrm{L}$. against $S$. aureus by disc diffusion method.

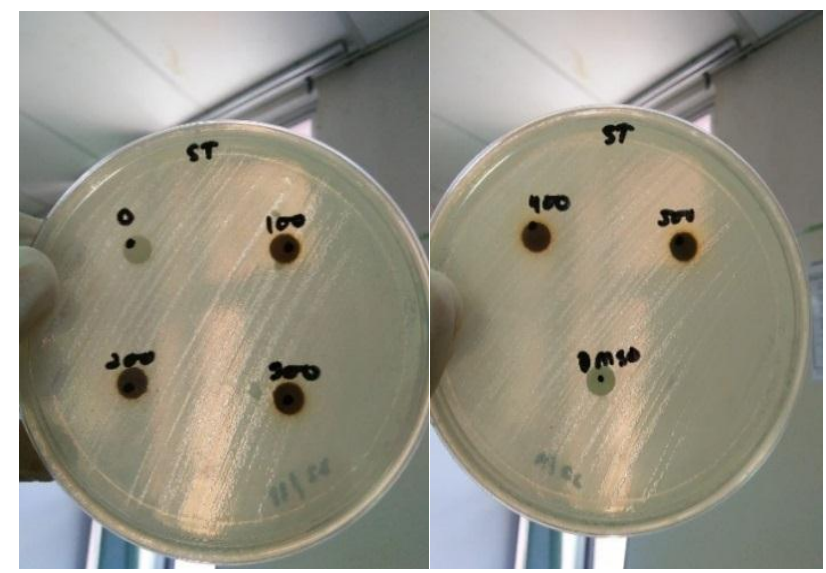

Figure 1b: Inhibition zone of $C$. longa $\mathrm{L}$. against $S$. typhi by disc diffusion method.

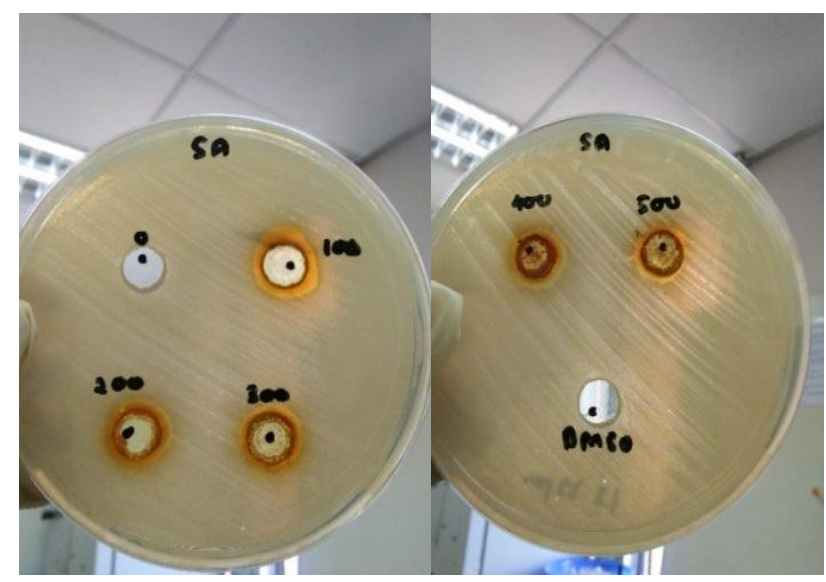

Figure 1c: Zone of inhibition $C$. longa $\mathrm{L}$. against $S$. aureus by well diffusion method.

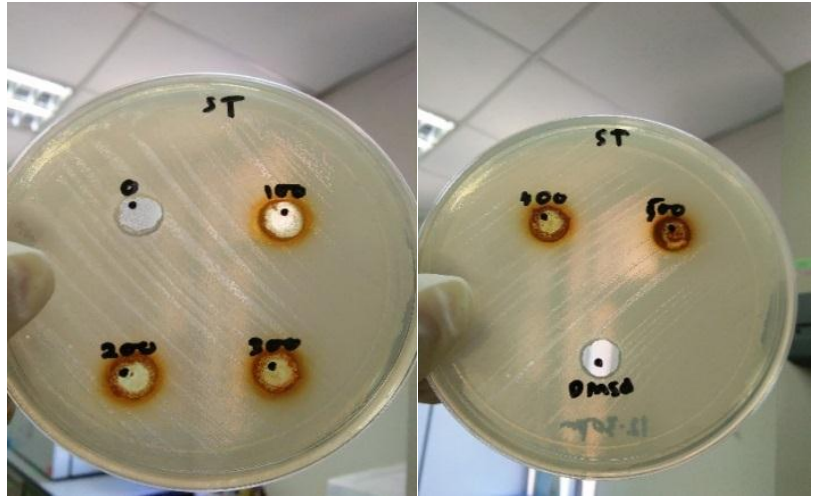

Figure 1d: Zone of inhibition $C$. longa $\mathrm{L}$. against $S$. typhi by well diffusion method.

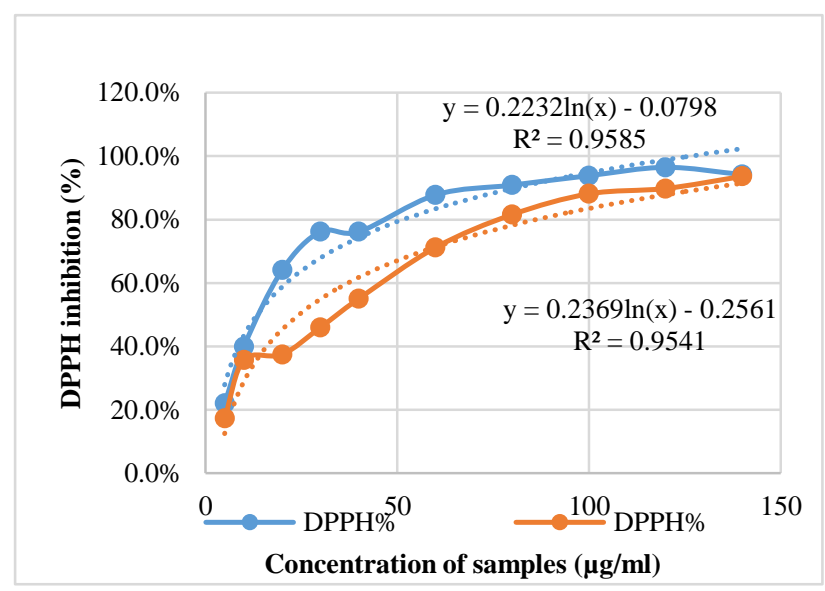

Figure 2: DPPH scavenging activities of C. longa Linn. rhizome extract compared to standard control butylated hydroxytoluene.

\section{DISCUSSION}

\section{Antimicrobial property of C. longa}

The results of both disc and well diffusion show that Gram-positive $S$. aureus bacteria were more sensitive towards the rhizome extract. At all concentrations (100$500 \mathrm{mg} / \mathrm{ml}$ ) tested, the ethanolic rhizome extract showed antibacterial activity with zone of inhibition of $7 \mathrm{~mm}$ against $S$. aureus. No microbial activity was determined by Gram-negative $S$. typhi bacteria. The structure of cell wall of Gram-negative bacteria attributed to its resistant to the plant extract. Gram-negative bacteria have an effective permeability barrier, comprised of a thin lipopolysaccharide exterior membrane which could restrict the penetration of the extruding the plant extract. Previous studies reported that Gram-negative bacteria usually more resistant to the plant-origin microbials and show no effect as compared to Gram-positive bacteria. Furthermore, Gram-positive bacteria have a mesh-like peptidoglycan layer which is more accessible to permeation by the extracts. ${ }^{9}$ 
Based on this study, the results indicate that agar well diffusion method proved to be more sensitive than the extract loaded onto blank disc. Large zone of inhibition yield in well method might be related to natural products transported by carrier compounds that expected to easily diffuse across the medium. Another factor would be the solvent used evaporate before placing discs on the surface of medium. Further, the extract expected to absorb to the surface of disc and not fully diffuse into the medium. However, disc diffusion method is a good and suitable use for testing antimicrobial susceptibility. ${ }^{13}$ Previous study on $C$ longa L. had similar finding. The minimum inhibitory concentration (MIC) results from Altunatmaz et al showed lower value $(125 \mu \mathrm{g} / \mathrm{ml})$ against Grampositive bacteria ( $S$. aureus and L. monocytogenes), than the value achieved against Gram-negative bacteria $(E$. coli and $S$. typhimurium) which is $250 \mu \mathrm{g} / \mathrm{ml}$. Other previous study of MIC values of curcumin by Wang et al reported $62.5 \mu \mathrm{g} / \mathrm{ml}$ for $S$. aureus and $250 \mu \mathrm{g} / \mathrm{ml}$ for $E$. coli. $^{2,14}$

In disc diffusion assay, there a few factors could influence the results. Firstly, the diameter of zones is affected by the rate of diffusion of the microbial compound. Thus, it may not exactly represent the potency of the extract's microbial activity. Furthermore, during the disc preparation technique, the extract may not properly and evenly impregnate into the blank discs. Another factor can influence the microbial activity of plant is standardization of the inoculum size to 0.5 McFarland turbidity. Important to ensure inoculum size because smaller inoculum size may produce falsely large inhibition zone and vice versa for bigger inoculum size. ${ }^{15}$

\section{Antioxidant property of C. longa}

In this study, DPPH radical scavenging activity of rhizome extracts and BHT increased as concentration increased. However, BHT showed the high scavenging activity with $\mathrm{IC}_{50} 12.42 \mu \mathrm{g} / \mathrm{ml}$. Meanwhile, $\mathrm{IC}_{50}$ value of rhizome extract is $21.25 \mu \mathrm{g} / \mathrm{ml}$. These reactions expressed that phenolics, flavonoids and tocopherols scavenge DPPH radicals by their hydrogen-donating ability. In addition, the results obtained in this investigation also reveal that the sample extracts act as free radical scavengers which might be attributed to their electron-donating ability. ${ }^{16}$

Oxidative stress plays a major role in the pathogenesis of various diseases such as hemorrhage and shock, myocardial ischemia, neuronal cell injury, hypoxia and cancer. It has been reported that curcumin in turmeric exhibit antioxidant activity by preventing lipid peroxidation in various cells including erythrocytes, liposomes and macrophages. In addition, the presence of phenolic groups in the structure of curcumin explains its ability to react with reactive oxygen species and reactive nitrogen species. ${ }^{17}$
This study applied DPPH method for antioxidant assay. The DPPH method is rapid, simple, accurate and inexpensive assay for measuring the ability of different compounds to act as free radical scavengers or hydrogen donors. It also rapid and simple method to evaluate the antioxidant activity of foods and beverages. ${ }^{11}$ Basically, the discolouration of a DPPH is associated with the number of electrons acquired which resulting in the existence of a free radical scavenger.

\section{CONCLUSION}

The results in this study showed that C. longa Linn extract had antimicrobial effects toward Gram-positive $S$. aureus bacteria. However, the results of rhizome extract had no antimicrobial effects on S. typhi. Besides, the ethanolic extract of $C$. longa $\mathrm{L}$. rhizome possessed antioxidant activity, that might be beneficial in prevention of various oxidative stress-related diseases. One of the limitations of this study is limited number of bacterial strains used. Future study should test the extract against various bacteria, viruses, fungi and parasites. Modifying the extraction by using other solvents such as methanol, DMSO and aqueous with minimum cytotoxic effect would also be suggested. Findings of this study provided information for further investigation on other pharmacological properties of turmeric.

\section{ACKNOWLEDGEMENTS}

Authors would like to acknowledge everybody involved directly or indirectly in this study.

\section{Funding: The study was funded by Universiti Sains Malaysia \\ Conflict of interest: None declared \\ Ethical approval: The study was approved by the Institutional Ethics Committee}

\section{REFERENCES}

1. Teow SY, Liew K, Ali SA, Khoo ASB, Peh SC. Antibacterial action of curcumin against Staphylococcus aureus: a brief review. J Trop Med. 2016:2853045.

2. Altunatmaz SC, Aksu F, Issa G, Kahraman BB, Altiner DD, Buyukunal SK. Antimicrobial Effects of Curcumin against L. monocytogenes, S. aureus, S. typhimurium and E. coli O157:H7 pathogens in minced meat. Veterinarni Medicina 2016;61(5):25662.

3. Gunes H, Gulen D, Mutlu R, Gumus A, Tas T, Topkaya AE. Antibacterial effects of curcumin: an in vitro minimum inhibitory concentration study. Toxicol and Indus Health. 2016;32(2):246-50.

4. Niamsa N, Sittiwet C. Antimicrobial activity of Curcuma longa aqueous extract. J Pharmacol Toxicol. 2009;4(4):173-7.

5. Qadir MA, Shahzadi SK, Bashir A, Munir A, Shahzad S. Evaluation of phenolic compounds and 
antioxidant and antimicrobial activities of some common herbs. Int J Analytical Chem. 2017;3475738.

6. Jamous RM, Abu-Zaitoun SY, Akkawi RJ, AliShtayeh MS. Antiobesity and antioxidant potentials of selected palestinian medicinal plants. EvidenceBased Complement Alternative Med. 2018;8426752.

7. Tanvir M, Hossen MS, Hossain MF, Afroz R, Gan SH, Khalil MI, Karim N. Antioxidant properties of popular turmeric (Curcuma longa) varieties from Bangladesh. J Food Qual. 2017;8471785.

8. Che Omar SN, Abdullah JO, Khairoji KA, Chin SC, Hamid M. Effects of flower and fruit extracts of Melastoma malabathricum Linn. on growth of pathogenic bacteria: Listeria monocytogenes, Staphylococcus aureus, Escherichia coli and Salmonella typhimurium. Evid Based Complement Alternat Med. 2013;2013:459089.

9. Biswas B, Rogers K, McLaughlin F, Daniels D, Yadav A. Antimicrobial activities of leaf extracts of guava (Psidium guajava L.) on two gram-negative and gram-positive bacteria. Int $\mathrm{J}$ Microb. 2013;746165.

10. Barry AL, Badal RE, Hawkinson RW. Influence of inoculum growth phase on microdilution susceptibility tests. J Clin Microb. 1983;18(3):64551.

11. Marinova G, Batchvarov V. Evaluation of the methods for determination of the free radical scavenging activity by DPPH. Institute Cryobiol Food Technol. 2011;17(1):11-24.
12. Rahim NA, Zakaria N, Habib SM, Mohd Azahar NMZ, Abdulla MA. Antioxidant activity of Alstonia angustifolia ethanolic leaf extract. AIP Conference Proceeding 1891. 2017;020012.

13. Balouiri M, Sadiki M, Ibnsouda KS. Methods for in vitro evaluating antimicrobial activity: a review. J Pharma Analysis. 2015;6(2):71-9.

14. Wang Y, Lu Z, Wu H. Study of antibiotic of microcapsule curcumin against foodborne pathogens. Int J Food Microb. 2009;136(1):71-4.

15. Razmavar S, Abdulla MA, Ismail S, Hassandarvish P. Antibacterial activity of leaf extracts of Baeckea fructescens against methicillin-resistant Staphylococcus aureus. BioMed Res Int. 2014;521287.

16. Nataraj L, Perumal S, Sellamuthu M. Antioxidant activity and free radical scavenging capacity of phenolic extracts from Helicteres isora L. and Ceiba pentandra L. J Food Sci Technol. 2013;4:687-95.

17. Trujillo J, Chirino YI, Molina-Jijon E, AndericaRomero AC, Tapia E, Pedraza-Chaverri J. Renoprotective effect of the antioxidant curcumin: recent findings. Redox Biol. 2013;17(1):448-56.

Cite this article as: Muhamed IA, Ahmad WANW, Ramli NS, Ghafar NA. Antimicrobial and antioxidant property of Curcuma longa Linn. Int $\mathbf{J}$ Basic Clin Pharmacol 2019;8:2383-8. 